\title{
Images of Francophone Countries and Francophone Images of the World
}

\begin{abstract}
Summary
A sample of mental maps of the world drawn by first-year geography students of eight Francophone countries reflects their variations in geography education. In several countries the geography students are unable to place 30 countries on their sketch maps of the world! The Francophone nations are not seen as the most important, for several large and wellknown countries appear more frequently than most Francophone countries on the sketch maps of the world from France and other Francophone countries of Europe, Africa and North America.
\end{abstract}

\section{Résumé}

L'analyse des cartes mentales des étudiants de huit pays de la francophonie illustre le rôle de l'enseignement de la géographie dans ces diverses nations. Dans plusieurs pays les étudiants de géographie sont incapables de situer plus de 30 nations! Cet article illustre également l'affaiblissement de la francophonie dans le monde: quelques puissances mondiales se substituent dans les cartes mentales à la France et aux pays francophones de l'Afrique, de l'Europe, et d'Amerique du Nord.

\section{Zusammenfassung}

Die Auswertung von "mental maps", gezeichnet von erstsemestrigen Geographiestudenten in acht frankophonen Ländern, zeigt die Unterschiede des Geographieunterrichts in den verschiedenen Ländern auf. In einigen Ländern waren diese Studenten nicht einmal fähig, 30 Nationen in ihrer Weltkarte einzuzeichnen! Aus der Untersuchung ist auch gut ersichtlich, daß die Bedeutung von frankophonen Ländern weltweit immer mehr abnimmt, da andere Nationen weit häufiger aufgeführt wurden.

\section{Francophone Images}

Between November 1985 and March 1987, 75 geography departments in 52 countries provided classes to contribute to a unique study, under the direction of Thomas F. Saarinen. On a blank sheet of paper students in first year geography classes at university were asked to draw a map of the world. The products of this simple exercise

Translation from French to English was done by John and Hilda Gourley. provided access to questions of identity and diversity, and to likely causes. Each national education system is responsible for the student images, along with the other informal ways of learning about the world.

This type of systematic enquiry provides a source of data which draws on the pioneering work of DOWNS and STEA (1973) and SAARINEN (1973). A first synthesis of this study was made by SAARINEN (1988). It illustrates the dominance of an Eurocentric image of the world, even after a quarter of a century of decolonization; but Americentric and Sinocentric maps appear also, illustrating other mental arrangements of the world. Several other papers based on the data set have been completed such as those dealing with the image of a single country (SAARINEN and MACCABE 1989, WALMSLEY, SAARINEN and MaCCABE 1990, SAARINEN \& MacCABE 1990), the use of sketch maps as surrogates for geographic knowledge (SAARINEN, MaCCABE and MOREHOUSE 1988), the comparison of the world images of the Commonwealth countries (1992) and a worldwide geographic education evaluation based on the sketch maps (SAARINEN \& MacCABE 1993).

In this sample, the Francophone countries were dealt with separately so as to study the homogeneity or diversity of their students' representations of the world, in relation to those of the students from the rest of the world. This yields the advantage of being able to compare the results of French-speaking students regardless of where they live (Europe, America and Africa).

Tallying the results of which countries were or were not present yields an accounting for each sample country. The aggregate results can easily be compared between countries, groups of countries, or continents. In all, samples from eight francophone cities were surveyed: Abidjan, Geneva, Lomé, Ottawa, Paris, Rabat, Ruhengeri, and Tananarive (Table No. 1). The Canadian sample was from the University of Ottawa.

Antoine S. Bailly, Prof. Dr., Département de Géographie, Université de Genève, Uni Mail, 1211 Genève 4, Suisse.

Charles MacCabe, Dr., 5403 Perrith Drive, Durham, N. C. 27713, USA.

Thomas Saarinen, Prof., Department of Geography and Regional Planning, The University of Arizona, Harvill Building, Box 2, Tucson, Arizona 85721, USA. 
Table No. 1

Number of Francophone Mental Maps By Site

Canada (Ottawa) Sample number

France (Paris)

Morocco (Rabat)

Ivory Coast (Abidjan)

Togo (Lamia)

Madagascar (Tananarive)

Rwanda (Ruhengeri)

Switzerland (Geneva)

Total

This sample of eight countries will be compared to those of the rest of the world, namely 450 out of a total of 3568 maps. We will begin by analysing the image of the Francophone countries by the students of the rest of the world before looking at the Francophone image of the world.

\section{The World's Image of Francophone Countries}

According to the total world sample, the frequency of Francophone (or partially Francophone) countries appearing on the maps varies considerably by nationality of the sample (Table No. 2).

Canada is the country most often named, followed by France, and an astonishing third, Madagascar. The first two can be explained by their size or historic importance, and the third owes its place to its cartographic position and shape. The world sample shows that island continents, like Australia, and maritime countries which are islands or have distinctive shapes or coastlines are better known (Italy, Spain, Saudi Arabia, Madagascar).

The stronger image of countries "at a corner" or at the edge of a continent explains why Morocco and Algeria appear on close to a quarter of the maps, which is more than their international importance would lead one to expect. Such is not the case with Switzerland, which is a small continental country, but famous enough to be mentioned once in every four maps. Those following demonstrate the Eurocentric nature of our images: a small European country like Belgium and Luxembourg appears frequently, while much larger countries of Black Africa are poorly represented. Only $1 / 10$ of the maps show Chad, Ivory Coast and Zaire, and the world sample has an even dimmer image of such large African Francophone countries as Mauretania, Cameroon and the Central African Republic.

The primary result is the dominant position of Canada, a country of continental dimensions. France holds a reasonable position due to its historic and cultural role and the Eurocentric emphasis of most of the maps. But it is only tenth in the world sample after Australia (91.1\%), USSR (83.8\%), Canada (79.9\%), Great Britain (79.7\%), USA (77.6\%), India (76.1\%), Japan (74.4\%), China (71.3\%) and Italy (61.6\%). This result for France corresponds to its new position as a medium world power. Madagascar is in 16th place with the other countries far down the list.
Table No. 2

Percent Inclusion of Francophone Countries by World Sample

Canada $80 \%$

France $62 \%$

Madagascar $\quad 50 \%$

Morocco 29\%

Switzerland $\quad 28 \%$

Algeria $\quad 21 \%$

Tunis $\quad 15 \%$

Belgium $10 \%$

Chad $10 \%$

Ivory Coast $\quad 10 \%$

Congo $\quad 10 \%$

Luxemburg $\quad 9 \%$

Zaire $\quad 9 \%$

Haïti $6 \%$

Senegal $6 \%$

Togo $\quad 5 \%$

Mauretania $\quad 5 \%$

Niger $\quad 5 \%$

Cameroun $\quad 5 \%$

Central Africa Republic $\quad 5 \%$

Burkina Faso $\quad 5 \%$

Mali $4 \%$

Benin . 4\%

Gabon $\quad 3 \%$

Rwanda $\quad 2 \%$

Djibouti $\quad 2 \%$

Mauritius $2 \%$

Upper Volta $\quad 2 \%$

Monaco 2\%

Seychelles $\quad 1 \%$

Andorra $\quad 1 \%$

Comoros $\quad 1 \%$

Vanuatu $\quad 0.1 \%$

Without a doubt, the educational system is responsible for these rankings of Francophone countries. There are, apparently, significant continental nuances too; as in African countries that know other Francophone African nations better, just as the Europeans know France, Switzerland and Belgium better. Geographic and cultural proximity undeniably is a factor in this.

\section{Francophone Variations in World Knowledge}

If we direct our attention to the sample in Table 3 of seven Francophone countries, we can see the frequencies of inclusion of various countries. The tendency is for the maps to be Eurocentric, even those of Canada, but the frequencies nevertheless vary from one sample group to another. The Francophone sample from Canada more frequently drew Eurocentric maps than the English speaking Canadian samples from Ottawa, Edmonton and Vancouver. Each of these samples contained some 
Table No. 3

Level of Inclusion of World Countries by Origin of Samples

\begin{tabular}{lcccccccc}
\hline Average & Canada & France & $\begin{array}{l}\text { Ivory } \\
\text { Coast }\end{array}$ & Togo & $\begin{array}{l}\text { Mada- } \\
\text { gascar }\end{array}$ & Rwanda & $\begin{array}{l}\text { Switzer- } \\
\text { land }\end{array}$ & World \\
\hline $\begin{array}{l}\text { Number of countries cited by } \\
\text { more than 90\% of respondents }\end{array}$ & 3 & 8 & 6 & 4 & 2 & 3 & 2 & 1 \\
\hline $\begin{array}{l}\text { Number of countries cited by } \\
80-89 \%\end{array}$ & 2 & 6 & 1 & 1 & 4 & 15 & 13 & 1 \\
\hline $\begin{array}{l}\text { Number of countries cited by } \\
70-79 \%\end{array}$ & 5 & 13 & 5 & 4 & 3 & 13 & 5 & 6 \\
\hline $\begin{array}{l}\text { Number of countries cited by } \\
60-69 \%\end{array}$ & 1 & 8 & 6 & 6 & 2 & 10 & 10 & 3 \\
\hline $\begin{array}{l}\text { Total of countries } \\
\text { Average number of countries }\end{array}$ & 11 & 35 & 18 & 15 & 11 & 41 & 30 & 11 \\
\hline cited & 29.2 & 56.9 & 38.7 & 38.5 & 23.4 & 61.7 & 55.6 & 35.7 \\
\hline
\end{tabular}

Americentric maps. The greatest proportion of Americentric maps were sketched by students in the sample from Vancouver, which is near the edge of the earth in a Eurocentric map of the world (SAARINEN 1988).

The Rwanda sample, like France and Switzerland, averaged more than 55 world countries. This encyclopaedic knowledge reveals an education of geographic nomenclature which is exceeded or equaled only by Hungary (76 countries), Germany (68), Spain (66), Kenya (63), USSR (60), Poland (58), and Norway (58). Three Francophone countries and some countries of eastern and western Europe thus yielded the best performance. For individual samples of such sketch maps see Figures 1-4. In contrast, many countries scored badly, which suggests a lack of geographic education in those places. In some cases it may be that the emphasis is on the teaching of geographic processes but not placenames. In the first case we have Madagascar which is on the same level as Brazil (18 countries), Turkey (21), Iran (22), one site in South Africa and Pakistan (23) and Bangladesh (24). The second case is that of the Francophone sample from Canada (figure 4) which is comparable to several samples from the USA (Fairbanks, Alaska 31 countries; Miami 33), Australia (Adelaide 32) and Italy (Milan 32). Thus the countries which have emphasized most of the teaching of process-oriented geography, like Great Britain and the USA, are found to be weak in their sketch map knowledge. This ignorance of the position of important countries of the world generates risks of ethnocentrism, since it is the neighboring countries that are most frequently mentioned. And how can one know and understand countries which one cannot put on the map? The knowledge of the names and the positions of the great countries of the world - by their size, culture, history and economy - constitutes a base for the learning of geography prior to the analysis of spatial processes. This knowledge provides the starting point for geographic study but not its final goal.

Pedagogic systems differ in the world in terms of what is taught in geography because of national ideologies and conceptions of the pedagogic role of geography. If it is possible to draw the line between different education approaches, then we suggest a demarcation between countries where geography students are incapable of placing 30 countries on the map and those where students place more.

\section{A Fading Francophone World}

To examine the relative importance of individual Francophone nations to selected samples we turn to Table 4. It tabulates the rank of representative Francophone nations in various samples. By using rank rather than raw percentages of inclusion we can better compare the relative importance even with samples of varying quality (SAARINEN, BALLANTYNE and MaCCABE 1992).

A sense of community is evident among the Francophone nations. They almost always rank the Francophone nations higher than the total world sample does. The only exceptions are: in the case of Canada where the rank is tied at third, and in the case of Switzerland, a near tie. The world total ranks Switzerland thirty-fourth and the Francophone nations rank it thirty-fifth. Switzerland is well known all over the world not just in Francophone countries.

The less well known the country, the greater is the difference between the world rank and the Francophone rank. Whereas Canada is the same in both rankings and France only two ranks higher; Rwanda and Ivory Coast are 48 and 57 ranks higher in the Francophone sample. The European countries France, Belgium and Switzer- 


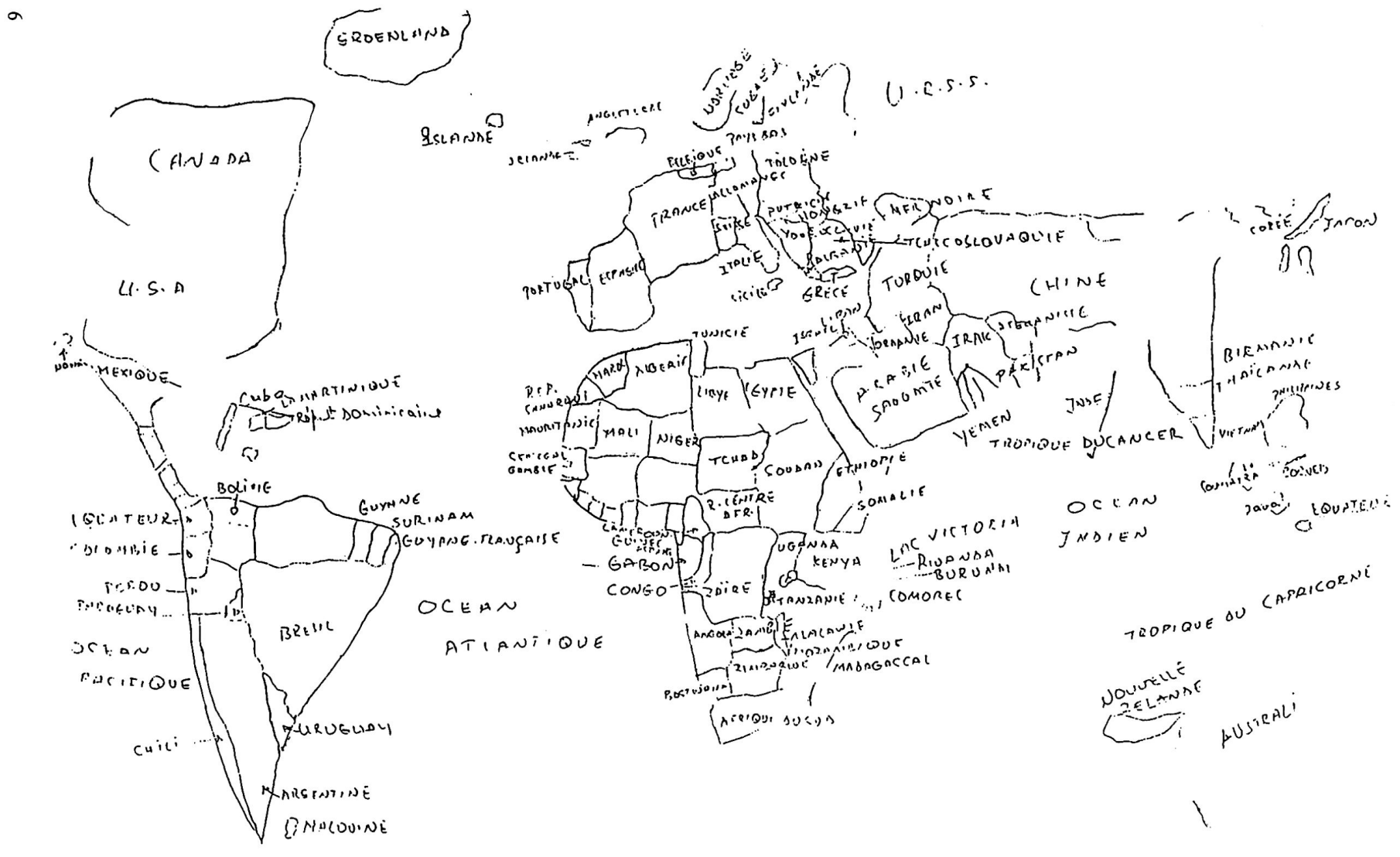

Fig.1 Mental Map of a Kigali, Rwanda, Student. 


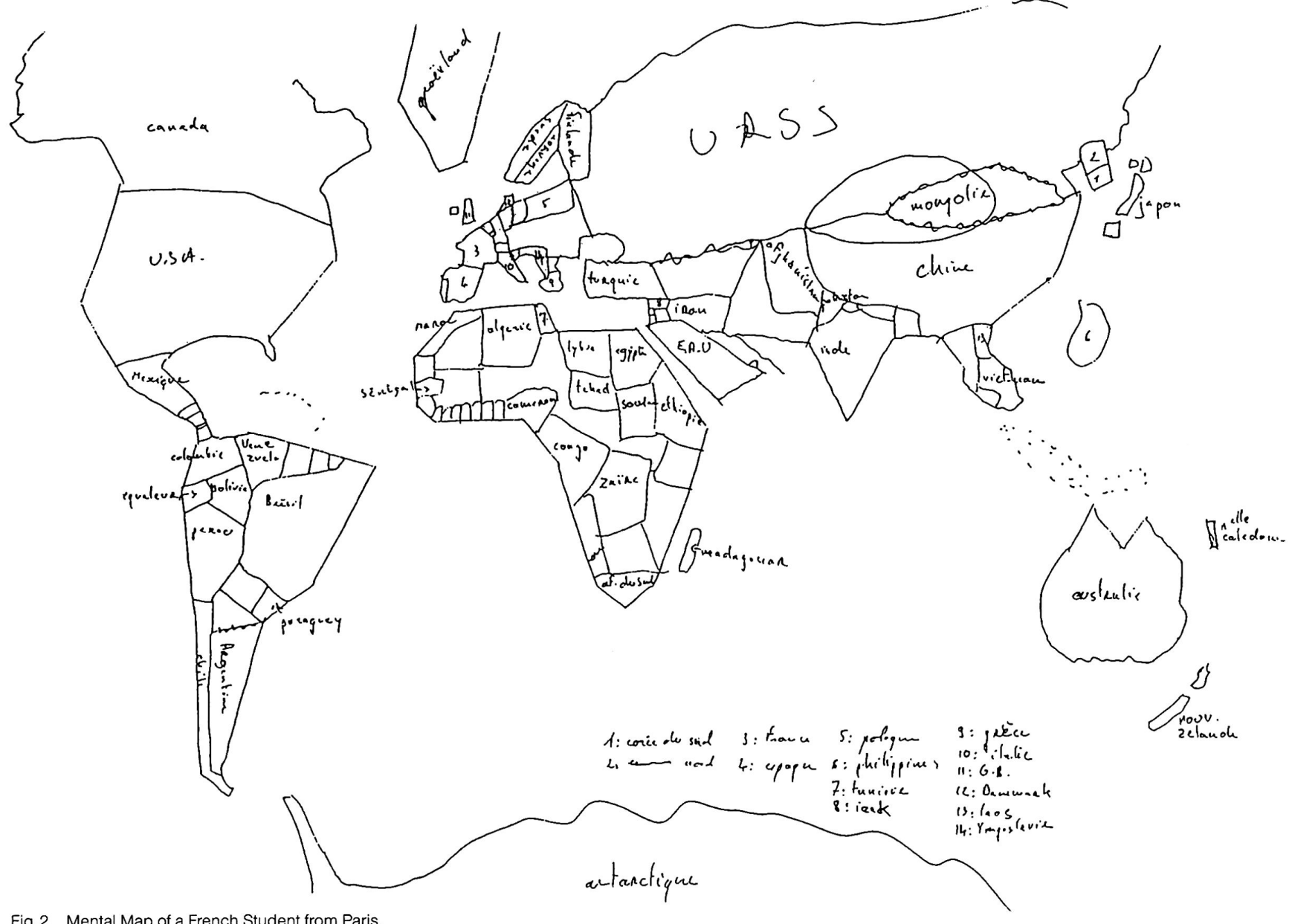

- Fig. 2 Mental Map of a French Student from Paris. 


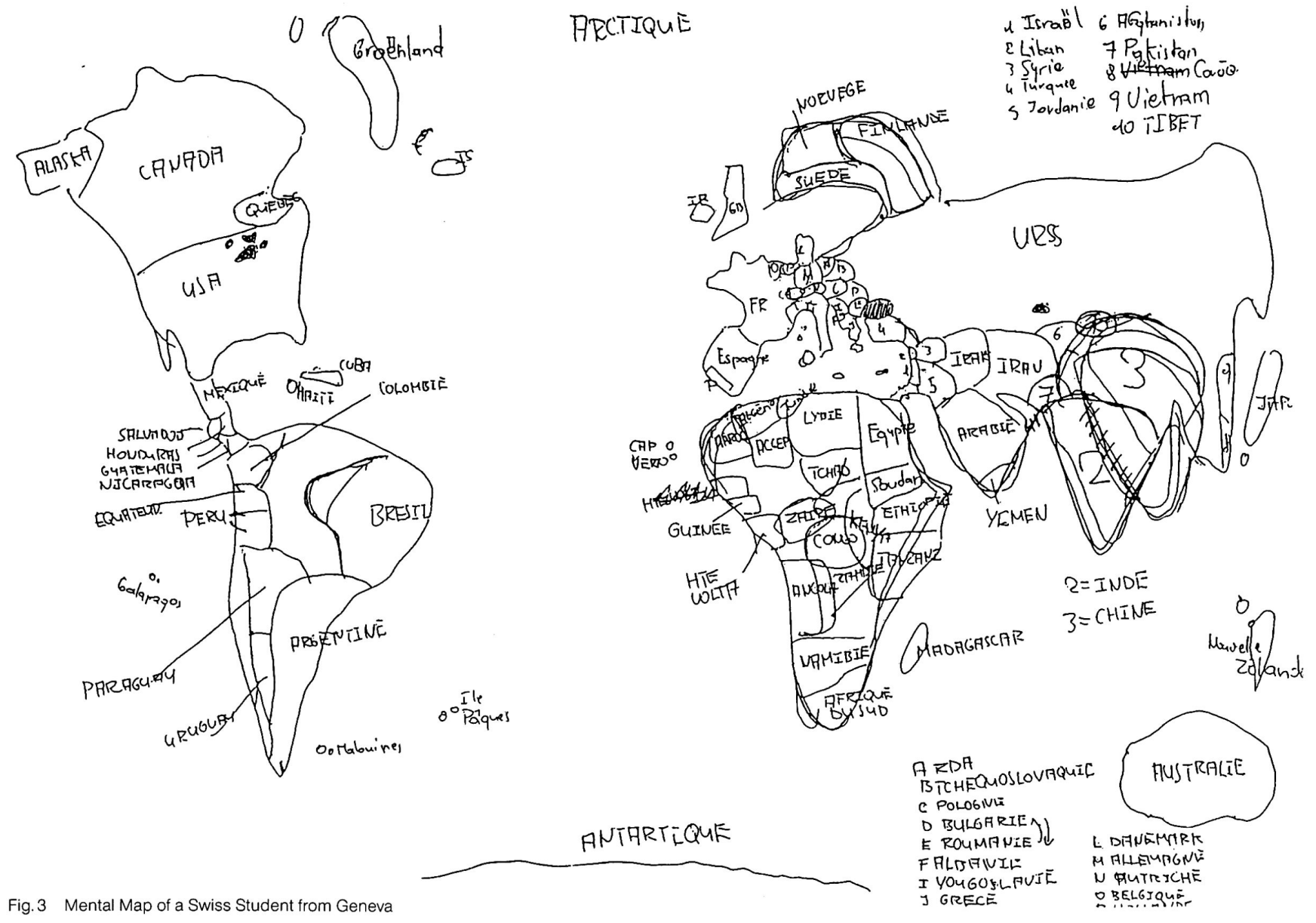




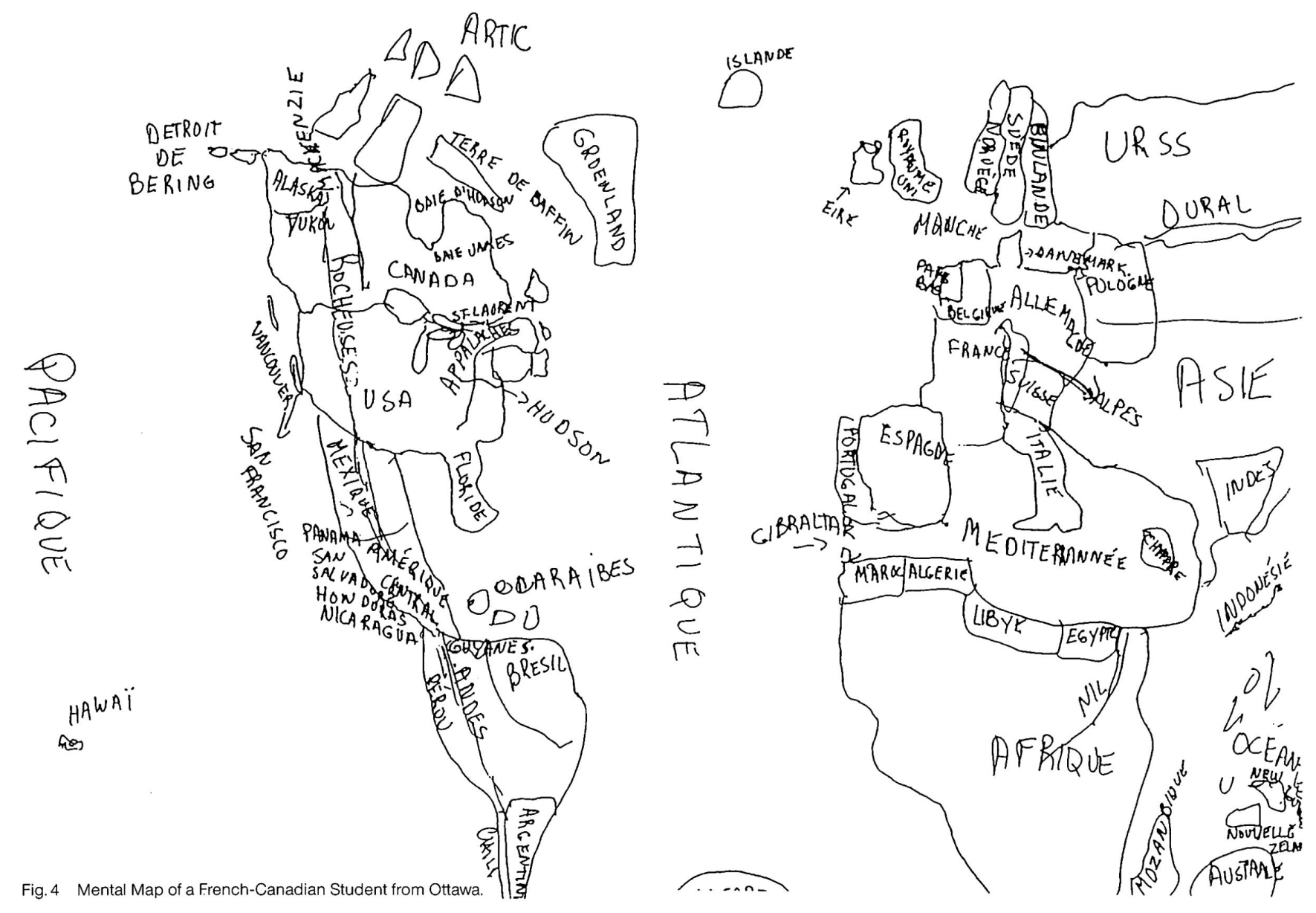


Table No. 4

Ranking of Francophone Countries by Selected Samples

\begin{tabular}{lccccccc}
\hline Country & World & $\begin{array}{l}\text { Francophone } \\
\text { Nations }\end{array}$ & $\begin{array}{l}\text { Ottawa } \\
\text { Canada }\end{array}$ & $\begin{array}{l}\text { Paris } \\
\text { France }\end{array}$ & $\begin{array}{l}\text { Abidjan } \\
\text { Ivory Coast }\end{array}$ & $\begin{array}{l}\text { Ruhengeri } \\
\text { Rwanda }\end{array}$ & $\begin{array}{l}\text { Geneva } \\
\text { Switzerland }\end{array}$ \\
\hline Canada & 3 & 3 & 1 & 3 & 2 & 9 & 9 \\
France & 10 & 8 & 8 & 3 & 8 & 19 & 3 \\
Madagascar & 16 & 5 & 18 & 20 & 5 & 9 & 3 \\
Morocco & 33 & 25 & 23 & 17 & 36 & 9 & 30 \\
Switzerland & 34 & 35 & 22 & 30 & 85 & 51 & 18 \\
Algeria & 48 & 26 & 37 & 15 & 31 & 9 & 19 \\
Belgium & 53 & 43 & 35 & 28 & 76 & 49 & 45 \\
Tunisia & 65 & 30 & 68 & 34 & 44 & 26 & 27 \\
Ivory Coast & 86 & 29 & 85 & 91 & 1 & 80 & 83 \\
Zaire & 91 & 45 & 80 & 95 & 43 & 4 & 60 \\
Rwanda & 137 & 89 & 111 & 136 & 39 & 9 & 121 \\
\hline
\end{tabular}

land are closer to the world rank than the African nations Madagascar, Algeria, Tunisia, Ivory Coast, Zaire and Rwanda. African nations are not generally well known in the world.

The Francophone rankings of various nations are not uniform throughout the sample. Generally the home country is ranked near the top, always much higher than either the world rank, or the Francophone rank. Furthermore neighboring countries are also ranked well beyond the world or Francophone rank. Thus, Belgium and Switzerland are ranked much higher by France than by either the world or Francophone samples. France is also ranked higher by Switzerland than the other samples. In the most extreme case Zaire is ranked 4 th by neighboring Rwanda, while the Francophone rank is 45 th and the world rank 91 st.

The world sample does not give the Francophone countries pride of place; nor does the total Francophone sample. There are not only numerous similarities but also some divergences, which lead us to ask ourselves about the cultural unity of the Francophone nations.

The great world powers have been substituted for the Francophone countries, illustrating the world dominance of some nations. From the results of the world sample, we obtain a vision of a world in which size is important, and where economic and political factors outweigh cultural factors.

First, none of the largest countries, the most important in terms of international role, or most geographically salient, fail to be placed: the former USSR is always well represented as are Australia, Great Britain, USA, and Canada. In a second group are China, France, Japan, Madagascar and India. Less well represented but still often mentioned are some European countries like Spain and Italy.

In other cases, the geographic dispersion of the results seems related to the place in which the map was drawn, because of the good ranking of their own country and its neighbors. This is apparent in the Rwanda sample. Zaire, a neighbor, is ranked fourth and African nations $R$ wanda, Algeria, Morocco and Madagascar are tied with Canada at ninth.

Thus, if the image of the Francophone community is diminished in a world of great powers, the Francophone nations remain linked, especially when there is a geographic, historic, or cultural proximity. A similar pattern appeared in the study by GOURLEY et al (1992) of the British Commonwealth countries. There, too, a fading image of the old British Empire and Commonwealth is found, with the African and Asian members on the verge of disappearing from the sketch maps of Commonwealth students.

\section{Conclusion}

The first lesson from the analysis of the mental maps of the students of the Francophone countries is that Francophonia is becoming more of a myth than a reality, with the political and economic weakening of France. The "baton is passed" to other world powers, Russia, Canada, USA, Great Britain, India, Japan, China, which have a stronger world image. With the cultural imperialism of the English language, the chances of a return of the former prestige of French are slim indeed.

The second lesson is that the role conceived for the teaching of geography greatly influences the knowledge of the place-name localities of the world. In several countries, students - of geography! - are incapable of placing correctly more than 30 countries ... Such ignorance is disturbing because, how can one study the spatial processes without having a minimal apprenticeship in learning the basic "vocabulary" of geography, the names of places? And how can one avoid ethnocentrism if students are limited to only a local image of the world? Without it 
being the aim of geography, the knowledge of a minimal nomenclature constitutes the "point de depart" for the study of a geography and is used as the means to expand ones horizons. Teaching can then be directed to the study of the great geographic processes. This is the pattern in countries more open to the outside world, because of their cultural practices or geographic curriculum. The choices for teaching geography will then depend on the individual national context vis-à-vis the larger world and on the attitudes of the students towards it. A basic geographic framework should precede the study of processes.

\section{References}

DOWNS, R. M., and STEA, D. (1973): Image and Environment: Cognitive Mapping and Spatial Behavior, Chicago.

GOURLEY, J., SAARINEN, T. F., and MacCABE, C. L. (1992): Commonwealth Students Map Images of the World. Paper presented at the IGU Commission on Geographical Education, Boulder, Colorado, August 2-7, 1992.
SAARINEN, T.F.(1973): Student Views of the World: In Downs \& Stea, ibid., pp. 148-161.

SAARINEN, T.F. (1988): Centering of Mental Maps of the World. National Geographic Research 4, 112-127.

SAARINEN, T.F., and MacCABE, C.L., 1988, The Finnish Image of the World and the World Image of Finland. In: Terra 101, 81-93.

SAARINEN, T.F. (1990): The World Image of Germany. In Erdkunde 44, 260-267.

SAARINEN, T.F., and MacCABE, C.L. (1993): Worldwide Evaluation of Geographic Education Using Mental Maps, paper presented at the Annual Meetings of the Association of American Geographers at Atlanta, Georgia, April 8th.

SAARINEN, T.F., MacCABE, C.L., and MOREHOUSE, B. (1988): Sketch Maps of the World as Surrogates For World Geographic Knowledge, in Gerber, R. and Lidmore, J. (eds.) Skills in Geographic Education Symposium, IGU Geographical Education Commission Proceedings, pp. 628-664.

WALMSLEY, D.J., SAARINEN, T. F., and MacCABE, C. L., Down Under or Center Stage? The World Images of Australian Geography Students. In: Australian Geographer 21, No. 2. pp. 164-178. 